\title{
米国のES細胞研究助成 仮差し止め命令、国外にも波及
}

\section{US stem-cell chaos felt abroad}

Meredith WAdMAN 2010 年 9 月 9 日号 Vol. 467 (138-139)

www.nature.com/news/2010/100907/full/467138a.html

ES 細胞研究への連邦政府助成を差し止める米国連邦地裁の仮処分決定で、

国際共同研究が危機に。

「裁判所の決定が確定すれば、我々の共 同研究は大幅に縮小されるだろう」。こ れは、8月下旬、カリフォルニア大学サ ンフランシスコ校グラッドストーン心 血管疾患研究所（米国）の発生生物学 者 Benoit Bruneau が、英国の共同研究 者に送った電子メールだ。Bruneau は、 米国立衛生研究所 (NIH) からの助成金 で研究を行っている。

Bruneau は、最近、ケンブリッジ大 学 (英国) のヒト肧性幹細胞 (ES 細胞) 研究者 Roger Pedersen との間で、心筋 細胞の発生に非常に大きな役割を果たす 特定の遺伝子ファミリーについての共同 研究を立ち上げたばかりだった。こうし た遺伝子の変異は、先天性心疾患、不整 脈や心不全に関与すると考えられてきて おり、このプロジェクトに対する熱意が 高まりつつあつた。

この共同研究では、Pedersen が、遺 伝子操作で疾患の原因となる変異を起 こさせ、蛍光標識したヒト ES 細胞を Bruneauに提供し、Bruneau が、この $\mathrm{ES}$ 細胞から十分に成熟した心筋細胞に 分化する過程で、関連する遺伝子がど のように機能するのかを分析することに なっていた。Bruneau は、自分の担当研 究の資金として、NIH の大型コンソーシ アム助成金を充てる予定にしていた。と ころが、8月 23 日、米国連邦地方裁判 所の Royce Lamberth 判事が、ヒト ES 細胞研究助成の違法性を争う訴訟を審
理する間、ヒト ES 細胞研究を対象とし た連邦政府助成金の交付に対する仮差し 止め命令を決定し、Bruneau らの共同 研究は存続が危うくなっている。もし助 成金交付停止が永続し、この共同研究が 頓挫すれば、「実に大きなチャンスが失 われてしまいます」と Bruneau は話す。

さらにPedersenは、こう話す。「Benoit はこの遺伝子ファミリーの世界的権威で あるため、この仮差し止め命令が、英 国内でのプロジェクト資金の調達、プロ ジェクト目標の達成と臨床現場への導入 の妨げとなるかもしれないのです」。
Pedersen は、Lamberth 判事の決定 が全世界に及ぼす影響を懸念している。 諸外国との共同研究が脅かされ、外国人 ポスドクは、米国へやって来た目的であ る研究プロジェクトが突然終了するか もしれない事態に直面し、海外での米国 に対する信頼が摇らいでいるのだ。米 国政府は、この決定に対して控訴した が、今後の法廷闘争や議会での論戦を 考えると、この研究分野は、最低でも 数か月は不確実な状況が続くことにな る。「米国政府の方針が、最長 4 年に一 度の頻度で変わりうるということは、ヒ ト ES 細胞の研究の発展にとって極めて 大きな障害となります。これこそがハリ ケーンであり、損失の元凶なのです」と Pederson はいう。

モナッシュ大学（オーストラリア・ メルボルン）の幹細胞研究者 Andrew Elefantyも、米国でのこうした状況が早 く解決しないと、自分の研究が影響を受 けると話す。Elefantyは、蛍光レポーター 遺伝子で標識された幹細胞株作製の専門 家で、こうした幹細胞株は、in vitroで の分化過程で、特定の細胞種の同定に役 立つ。同じ研究室の共同主任を務める Elefanty と Ed Stanley が、2008 年以

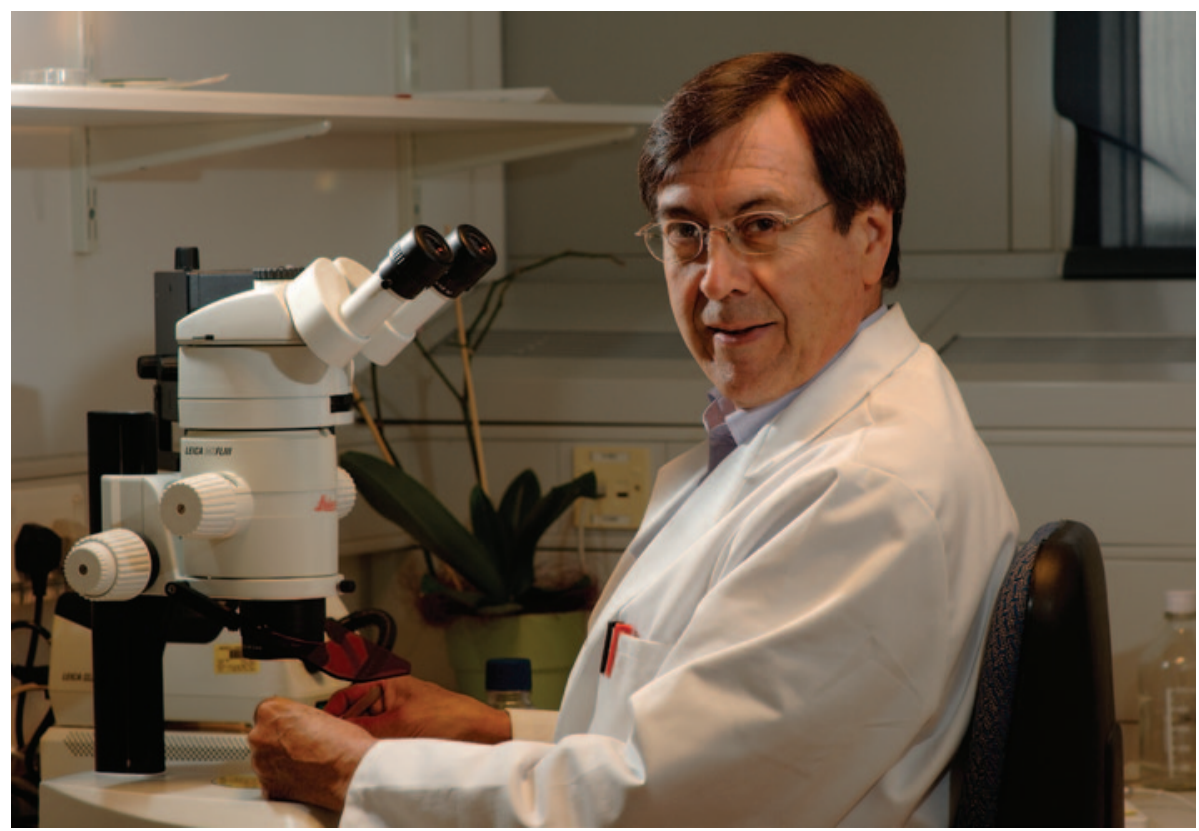

Roger Pedersen は、ヒト ES 細胞研究を行うためにカリフォルニアを離れたが、今度は米国 内の共同研究者を失うかもしれない。 
降に立ち上げた、あるいは現在計画中の 21 の国際共同研究のうち、13 件に米国 の研究グループが参加している。

Elefanty は語る。「心配なのは、米国 内の不確実性によって、共同研究が制約 を受け、我々の研究成果の質にも波及し てくることです。我々の研究は、本当に 質の高い科学研究を実践できる共同研究 者にかかっているのです」。

今回の連邦政府助成金交付停止命令に よって、海外の研究者が直接影響を受け る可能性もある。米国内で同じ内容の研 究を行う者がいなければ、海外の研究 者が NIH から助成を受ける資格を得る からだ。オーストラリア連邦科学産業 研究機構 (メルボルン) の幹細胞研究 者 Andrew Laslett は、ポスドク時代、 3 年間 NIH の大型共同研究助成金から 給与をもらって、ヒト ES 細胞から腎臓 前駆細胞を誘導する研究を行った。「私 の研究キャリアは、この助成金によって 本格的にスタートしました。現在の共同 研究者に出会ったのも、自分で最初の助 成金を獲得できたのも、NIH の助成金 によるポスドク時代のおかげです」と Laslett は話す。だからこそ彼は、米国 にいる共同研究者の一部が、助成金を受 け取れなくなったというニュースを聞い て、「身が縮む思いをした」といっている。 米国内で働く外国人ポスドクは、さら なる不確実性に悩まされている。米国内 で研究を続けるべきかどうかを直ちに判 断しなければならないのだ。「今は、す べてが落ち込んでしまっているような感 じです」っこう話す Adam Goulburn は、 Elefanty の研究室で $\mathrm{PhD}$ を取得し、8 月からコーネル大学ウェイル医学校 (米 国ニューヨーク）の Stewart Anderson 研究室で、ポスドクとして働き始めたと ころだ。Goulburn は、ヒト ES 細胞か ら純粋な介在ニューロン集団を誘導する ことをめざしている。発生中の脳におけ る介在ニューロンの移動や機能の異常 は、自閉症、てんかん、統合失調症といっ た疾患に関与すると考えられている。こ のプロジェクトが直ちに危機的状況に陥
るわけではない。しかし、今後、現在支 援を受けている民間からの新規事業準備 資金について、究極的には、これまで の NIH からの助成金に見合う増額が必 要となる。Anderson は、もし今回の差 し止め命令が確定すれば、長期的には、 Goulburn のプロジェクトに資金を獲得 できなくなってくる、と語る。

今後、「非常に才能があり、十分な教 育を受けた、Adam のような世界の幹細 胞研究者が、米国以外で研究経験を積も うとするようになるかもしれません。幹 細胞研究は今後も継続し、どんどん発展 していくでしょう。ただし、それが米国 内では起こらない、ということです」と Anderson は話す。

一部の外国人ポスドクは、あきらめず に米国での研究を続けることを決めてい る。カリフォルニア大学サンフランシス コ校糖尿病センターに所属するオランダ 人ポスドク Dennis Van Hoof は、民間 の助成金と州の助成金を受けている。自 身も 1 型糖尿病患者であるVan Hoof は、
今回の仮差し止め命令で自分の計画が変 わることはない、と話す。彼は、オラン ダ国内では行われていない 1 型糖尿病に 対するヒト ES 細胞の応用研究を行うた めに、米国にやって来た。ただし、自ら の研究に連邦政府の助成金が得られる見 込みは、非常に不確か」だと認めている。

Pedersen は、米国内で研究を続ける 同僚のことを思うと悲しくなる、と話 す。彼は、2001 年にカリフォルニア大 学からケンブリッジ大学に移った。それ は、ジョージ・W・ブッシュが米国大統 領に選ばれ、Pedersen が NIH に、初め てのヒト ES 細胞研究に関する助成金申 請を行い、即座に棚上げされた後のこと だった。

当時を振り返って、Pedersenは、次 のように語る。「あれが正当だったとは 思いません。むしろ、理不尽だったと 感じています。米国は私の母国です。 今回の件で、米国は痛手を受けたと思 います」。

(翻訳 : 菊川要) 